\title{
Pedagogical Analysis of Catastrophic Visions of Art
}

\author{
Barbara Kwiatkowska-Tybulewicz \\ University of Warsaw, Poland \\ E-mail address: b.kwiatkowska@uw.edu.pl
}

\section{ARTICLE INFO}

\section{Keywords:}

Art

Education

Crisis

Aesthetic education

Education through art

Article history:

Received 20 October 2014

Received in revised form 1 May 2015

Accepted 31 August 2015

ISSN: 2354-0036

DOI: 10.1515/ctra-2015-0023

\begin{abstract}
A B S T R A C T
The theory of aesthetic education treats art as an educational space. It is interesting to look at theories of the end of art from a pedagogical perspective. The article presents a few selected items, symptoms of the collapse of art, which have appeared in theories of a crisis of art. Are they relevant to the theory of aesthetic education? Is education "for" and "through" art justified in the face of the end of art? In this article the author presents catastrophic visions of art from the pedagogical perspective.
\end{abstract}

"Art (...) will be dying slowly, among terrible visions and nightmares, among fatal vomiting and bleeding, among convulsions and hideous seizures" (Witkiewicz, 1992, p.146). A shocking image, like Michelangelo's Last Judgment in the Sistine Chapel, weeping and gnashing of teeth. This time the object which is being judged will not be condemned, and will not be raised to heaven, but simply will die, cease to exist. This is the future of art, or rather this will be the end of it. Theories about the end/death or a crisis of art are not a new phenomenon. Hegel in his philosophical reflection on the end of art claimed that a certain function of art is over. Art has lost its exposed position: it has ceased to be the seat of the soul. Art, abandoned by the spirit, has become an empty shell, not mediating between consciousness and an idea, no longer worthy of any attention (Hegel, 1975). Dissemination of the Dadaists' thesis about the death of art, was undertaken, inter alia, by Nietzsche, Benjamin, Heidegger, Adorno and several other contemporary philosophers.

A crisis combines with collapse, with disruption of the existing order and a state of equilibrium in a specific area. Regardless of the field to which it relates, a crisis is a turning point, that causes either a state of total destruction, or provokes constructive 
changes which set new directions of development. At the beginning of the twentieth century, theories presenting the threat to art, its crisis and the beginning of the collapse of the artistic world intensified. Around this time, great changes in art began, the effects of which we still feel today. Since that time, which means from the beginning of the twentieth century, we have talked about "the new art" which has given rise to contemporary art, recognized in a broad sense. There has been a slow but consistent retreat from figuration to abstraction in the artistic area. These changes have led to broadening the scope of acceptable topics and formal solutions in the artistic world. Beginning from Impressionism (which began a period of great artistic experiments and was the first serious intrusion in the stable order of Renaissance artistic culture), through the "wild beasts" of Fauvism (with its purple trees and red skies), and Cubism (which was a step forward in deepening deformed figures), getting closer to Surrealism (violating natural compounds and cause-and-effect relationships) to Duchamp's ready mades, where works of art were items, which would have never been named this way by its recipients.

Non-figurative works of art proved to be a significant expansion of the creative activity. Audiences, already accustomed to artistic experiments but always based on the notion of figuration, suffered a great shock in contact with the works of Kandinsky, Malevich and Mondrian. The new works of art were outside the definition of what had previously been considered an artistic creation. The first time the recipient was in a situation, in which, while in contact with the work of art, instead of wondering why the artist had presented the figure in that form, they had to ask the question: "What is it?" There were immediate discussions about the cause of the withdrawal of artists from direct contact with reality, renouncement of the principle of mimesis and abandonment of classical beauty. Explanations for the collapse of art were sought and considered. It is interesting that this process was not to come in the distant future, but had already taken place in the twentieth century, and is consistently bringing its work to a spectacular finale. A finale which for some is close, for others has long since arrived.

The question of the end of art is extremely interesting when we look at it from a pedagogical perspective. Art is connected with basic human needs, namely the need to express our emotions, feelings and experiences related to the imagination. The need to express and reinforce ourselves, produce objects, inspire emotions, seems to have been attributed to man from the very beginning, in any event, from the moment when mental development allowed us to efficiently use abstract concepts. The evolution of art contributed to the variety of works belonging to this category. The acceleration of development that took place in the twentieth century, increased the frequency of the emergence of new 
trends in art, including more and more areas which had, until then been independent of the kingdom of art, were now drawn into the artistic world. We might perceive this situation as an increase of vitality in art. Sometimes it is perceived inversely. Art, as the product of man, is subject to the same laws as all other things which concern him. Works of art emerged in the public space to get to those recipients who did not have the time (or desire) and maybe enough will power to go to galleries. Art has tried to come out into the streets and "accost" the passer by, but at the same time it is drawn in by the entertainment industry, it is consumed, processed and used for commercial purposes. The combination of these two processes is called by some the new field of impact of art, others perceive it as degradation and the ultimate end of art. Today there are strong reactions to contemporary art. Some people offer a big hurrah for the way in which art has broken conventions that have dominated it for ages. Others think that "true art" has been lost and in the future art will cease to be different from everyday life, it will disappear and melt, the main form of its presentation will vanish. In the course of our lives several spoken languages will disappear forever, because their potential has been exhausted. The potential of the species is low, the potential of communication channels too. Maybe the next one will be art?

\section{CATASTROPHIC VISIONS OF ART IN DIFFERENT THEORIES OF ART}

What might indicate the crisis of art? Looking at various theories, we can identify several elements, announcing the collapse of art. I will try to introduce some of them briefly.

The first element is the announcement of traditional transcendent values. The future of art, which is deprived of any support in the metaphysical context of the Mystery of Existence, is doomed. In a world, where religion has been reduced to routinely repeated practice and faith in the deep axioms has been replaced by the cult of usability and universal happiness, art is going to collapse. Stanislaw Ignacy Witkiewicz did not see any form of rescue for the art world in the early twentieth century. He diagnosed the state of art as agonal. His catastrophic vision of the convulsive death of art came from two sources: from having exhausted the possibilities of formal art and the disappearance of any metaphysical sensibilities in artists and audiences. In general, we can say that metaphysics has been abandoned, as it has become incomprehensible to man. Pure Form is an expression of the artist's metaphysical shock and it is a source of the same metaphysical shock for the audience. Unfortunately, the metaphysical sensitivity of mankind has fallen in the course of social evolution. Fear and focus around the Secret of Being are hailed as old-fashioned superstition. The decrease of metaphysical sensitivity determines deepening "insatiability of form": form becomes more and more complicated, but 
the possibilities of combination are exhausted. In this situation, true art becomes unattractive to the public and will have to die. Single individuals, representing real artists, will for some time contend with the phenomenon called "insatiability of form". The fate of art is therefore decided: there will not be anybody to create, nor anybody to create for. Art will disappear, and its place will be taken by entertainment (Witkiewicz, 1992). In Witkacy's theory we have two causes of the collapse of art: an external one - expected world revolution, which began in Russia and will destroy the world and the whole of art; and an internal one - the exhaustion of art itself (as described above). For more than two centuries we have been losing contact with the sacrum. The experience of the sacrum includes a certain mystery, rising above the ordinary, striving to capture transcendence of what is deepest and cannot rationalize the meaning of our existence. Today, all the energy and interest of people focuses on economics, science and technology. Existential problems have been moved aside. The world is ruled by the laws of the market, which rule almost all aspects of human life. In today's world we can say that the more I am, the more I have. It is not hard to see that the sphere of "being" has been marginalized and overwhelmed by the sphere of "having". Fromm writes: "In a culture in which the supreme goal is to have- and to have more and more - and in which one can speak of someone as "being worth a million dollars," how can there be an alternative between having and being? On the contrary, it would seem that the very essence of being is having; that if one has nothing, one is nothing" (Fromm, 2008, p.13). The process, which was noticed by Witkacy, is escalating today. Acceleration of the pace of life has brought changes in the way of perceiving art. A viewer does not stop in front of a work - he expects a rapid change and an interesting form. Art does not show a universal image of the world, it has become an indeterminate text, deprived of the possibility of one definitive understanding, which should not be recognized as something negative. However, from Witkiewicz's perspective, this would be an element indicating the collapse of art. Kuspit has a similar view: "It seems almost absurd to claim that you can pass a universal artistic vision in a world, where there is no universal experience, but a variety of culturally determined experiences. In such a world, art is just another interpretation of one of the cultural versions of everyday life, but not a revolutionary challenge for the latter" (Kuspit, 2006, p. 163).

Witkiewicz mentioned the progressive disappearance of metaphysical feelings in society for overall happiness. Art removed from its pedestal and stripped of the Mystery of Existence has become available to the masses. It was a step that began the conquest of the kingdom of the artistic world by the kingdom of commerce, not ruled by demanding or spiritual masses. Here arises a new threat for art, namely the democratization of art. The democratization of cultural values was a great opportunity for mass society, which 
was provided with higher values, as we all know art is a carrier of humanistic ideas. However, this chance was wasted and the experiment "pulled" art "towards the ground" leaving a trace on its condition. The masses were not interested in artistic creativity and contemplation, but wanted to improve their everyday existence. They wanted to highlight their increasing position in the modern world, so they captured art, which was previously reserved for the intellectual elite. Abolishing the existing barriers, the masses wanted to grasp what was not previously available to them. However, the cultural delay of these liberated masses and their systematic abandonment of the spiritual world for the scientific one and civilized order, resulted in turning towards the trash, kitsch and novelty of the miserable (not to say no) artistic value. Adorno in his Aesthetic theory said, that succumbing to the influence of cultural industries is a matter of choice. The bourgeois character has a deep inclination to choose worse things from cultural offers (Adorno, 2002, p.350). In other words, the masses will direct their attention to the contents, which will be easy and enjoyable. Art, which is difficult, reaching for dissonance, requiring intellectual effort, knowledge and savvy - will be rejected and marginalized by the masses. It is an interesting fact that in the consciousness of mass society, which values specialization, general education (often apparent) and blind reliance on the opinions of "experts", reigns the view, that what we have to deal with on an everyday basis in the media, is a piece of art. One noisy advertisement of a product, full of "artistic value" is enough to convince a man of the masses that this is a part of the artistic world. The variety of perishable ideas, multiplicity and instability of artistic trends, implies a deep confusion in contemporary art and predicts the end of art. Witkiewicz was upset by the fact, that every "artist" can invent his own "ism", set up a school and promote a style, which will not necessarily be called "artistic style", but unfortunately will be considered art.

It seems that nowadays the mass media have taken over the role of educating society. Since art started to appear more often in the media, the consumption of works of art has increased, and has started to be regarded as good, subject to trade. Art has become a commodity. This is the third element, which heralds the collapse of art. An abolition of formal barriers in contact with artistic objects is not identical with the common understanding of pieces of art, the nature of which exceeds the cultural competence of an uneducated viewer. It leads to the domination of elements of mass culture in art, creation "for the public", it does not trigger intellectual effort in a recipient, but it only brings simple, uncomplicated and banal entertainment.

Adorno connects the loss of higher values with the reign of commercial culture. He draws attention to the destructive mechanisms of commercialization of the most outstanding tracks, tailored to the needs of the average consumer. Art loses its sense 
(Adorno calls it a metaphysical sense) by interfusion with various disciplines, dislocation of the boundaries between them, blurring the means of expression, and dominance of the phenomena of mass culture, which push art into oblivion. The cultural industry generates needs, which it then satisfies. This also applies to "aesthetic" needs. For this reason, the audience moves away from art, which seems to be inadequate in relation to contemporary social life. The best art seems to be one, which is most easily consumed. Therefore, art is dying in the sense, that it cannot exist outside the official cultural system - each work of art inevitably turns into a consumer product. "Cultural industry raised its victims so that in hours of leisure, destined for the spiritual consumption, they would avoid the effort, so these victims with increasing persistence cling to fiction, which covers the essence of things" (Adorno, 1974, p.40-41). Art is subjected to neutralization by including it in the system of social consumption. Satisfaction from the prestige, which is supposedly given by interaction with or possession of a piece of art, becomes the most desirable. Adorno mentions a recipient of Toscanini's concert, who was most pleased with the fact, that he had paid a lot for the ticket (Adorno,1990, p.109). He indicates the fetishistic nature of works of art (the next portent of the collapse of art). In addition to the criticism of the commodification of art, Adorno objects to a situation in which a work of art is treated as a machine to meet all kinds of needs (not excluding aesthetic ones). The assumption, that a work of art should "give something" to the recipient, is petty bourgeois. Experiencing art as something which can be consumed is a crime with regard to art itself.

Modern society is a creation, which is consumer-oriented and, according to Bauman (2000), seeks primarily to satisfy its needs and pleasures. It consists of bored individuals who believe in one truth, namely the truth of the TV screen (or a computer screen). In this case, stimulation of modern man, breaking him out of sleep and dreams concerning entertaining reality, is extremely difficult. The subordination of art to purely hedonistic ideals changes the expectations of consumers towards works of art and begins the reign of "pseudo art" which is a creation replacing a piece of real art. Its task is to satisfy the need for fun and entertainment not only of the representatives of the wealthy classes, but mass society as well. This problem was seen similarly by Read: „We are witnessing not only disintegration of form in art, but disintegration of the intelligence, the fall pulling us to "a marketplace of entertainment" without an end, not funny at all, but hell, to which alienated intellectually and morally blind vandals of urban economics come down in their ruthless search for any object on which they could vent their destructive energy" (Read, 1973, p. 174).

Reducing creative expression to a model appropriate for the average recipient is associated with the collapse of the creative nature of art, which in its creative form turns out 
to be incomprehensible to the viewer. The result of this is simplification of art and adaptation to mass reception, which unfortunately takes away all artistic value. Misunderstanding of art is another element predicting the end of art. Democratization, which I mentioned earlier, has allowed the masses to approach art, which by itself does not mean understanding it. In the absence of agreement between artists and audience, the latter have forced art to adapt to their level of understanding. Rejection of higher forms of art has turned out to be the only way for mass society which, on the one hand, did not want to admit their insufficient education and inadequate level of development required for understanding art, and, on the other hand, did not want to take the smallest initiative to increase and expand their own artistic awareness. In this situation more difficult art forms have no recipients. The problem is that the average consumer who is still looking for aesthetic values in art, evaluates art through the prism of beauty, and is unwilling to see other forms of artistic expression. It is very difficult to convince the audience that art can remain art even in a situation where beauty is not the most important category. Lack of traditionally understood beauty is often seen as a harbinger of the collapse of art.

Ortega y Gasset notes that contemporary art divides the public into two groups: those who understand it and those who cannot. „This implies that one group possesses an organ of comprehension which the other is deprived of - that there are two different types of human species. The new art obviously is addressed not to everybody, (...) but to a specially gifted minority" (Ortega y Gasset, 1956, p.6). Hence flows the discontent of the masses, whose aversion to art is due to their failure to understand it, failure which humiliates them, and this annoying feeling of inferiority leads to rejection of the object of misunderstanding. „When a man dislikes a work of art, but understands it, he feels superior to it and has no reason to feel indignant.(...) The new art, just through its mere presence, forces an average citizen to realize that he is only an average citizen, a creature incapable of receiving the sacrament of art, blind and deaf to pure beauty. (...) Accustomed to domination in all aspects of life, the masses feel that the new art, which is the art of privileged aristocracy of finer senses, endangers their rights as men. Whenever the new Muses present themselves, the masses bristle" (Ortega y Gasset, 1956, p. 6). At this point we may also notice "the emancipation of detail" mentioned by Adorno. Emphasizing detail leads to the loss of the ability to participate in works of art as a complex whole. Adorno sees this clearly in popular music which attaches a listener to a fragment taken out of a context. Adorno said that: "from all elements of traditional music the audience understands only the most primitive ones: ideas you remember, sentimental and beautiful places, moods and associations. Reasonableness and consistency of music 
for stupid radio listeners is as inaccessible in the early Beethoven sonata, as in a Schoenberg Quartet" (Adorno, 1974, p. 40). The place of an authentic work of art has been taken by "a spectacular effect." The audience is looking only for such moments, which satisfy their aesthetic needs and they do not feel any need to interact with the full work of art. This manner of reception of art contributes to the end of authentic works of art.

The faith of a modern man in the power of the intellect has caused domination of thinking about art over artistic creativity. The advantage of theory over practice is another symptom of the collapse of art. The emergence of art critics is, according to Tolstoy, an important element of the crisis of art, where creation is slowly dying off, where expressive creation is only theoretically discussed. Explanation of creative expression may only be apparent, as it is irreducible to the field of words (Tolstoj, 1980).

Ortega also notes that intellectualism has become the driving force of life. There has been some reevaluation, consisting of an advantage of the intellect over life. Life matters only if it arises from intellectual reasons. Modern man has sunk into knowledge and information. Furthermore, we can refer to Kuspit, who says that social information is being sold as art.

The last element, which may indicate the crisis of art, is blurring of the boundary between art and life. This element appears frequently in theories talking about the end of art. Kuspit expresses himself very bluntly: "When contemporary art cuddles up to everyday life and identifies with it, it cuddles up and identifies with the enemy, what in turn is a suicide" (Kuspit, 2006, p.62). Therefore Kuspit is opposed to "blurring the boundaries of art and life" of Kaprow and the "art as experience" of Dewey. Everyday experiences have become the aesthetic sensations of everyday life. Everyday items are advertised as objects of art. Today we glorify everyday reality under the guise of making an analysis of it. The boundary between creative imagination and banal reality is abolished: the aesthetic thus becomes ordinary. Kuspit very sharply declares that art turns to the streets, when it loses its vital role in life. Becoming a part of the street, it turns into "post art", which is easily confused with everyday life. Art has come down from its pedestal to mingle with crowds, but it is not good for it (Kuspit, 2006, p.141). Art has lost emotional and existential depth, moved away from spirituality and integrity, abandoned beauty, assimilated with money (Kuspit, 2006, p.154). According to Kuspit, all these elements clearly indicate the end of art.

The situation of art today is closely linked to social and economic phenomena. "Contemporary art contains the same elements of rebellion and degradation, violence and disintegration, destruction and reconstruction, which constitute, what has now become a political Europe, inner ambiguity" (Read, 1973, p. 165). The vision of the collapse 
of art appears in programmes carried on the wave of general anarchy in culture. Desacralization of art, subordinating it to hedonistic ideals, democratization, the advantage of thinking over practical creation, and finally, commercialization, according to the presented theories, make it lose its identity. As you can see from the examples presented above, the crisis of art is seen, inter alia, in the absence of metaphysical feelings, transcendence and depth, exhaustion of aesthetic values, abandonment of aesthetic pleasure and beauty, in commercialization, commodification and fetishization of art, as well as dissemination and democratization of art, which simplifies and brings art closer to a banal, everyday life.

\section{VITALITY OF ART IN PEDAGOGICAL TERMS}

Despite such an image, art is still here (although for some it is already "pseudo art"). Reflecting on education through contemporary art, we should keep in mind that the practice of such education evolves. The aesthetic of beauty implied a concept of education based on an interaction with ideal beauty. A man could be subjected to the formative influence of beauty and in this way he could pursue his own harmony and perfection. The role of art was recognized in the education of man according to different views in a more traditional sense. Looking at contemporary art from this perspective we are unable to find its educational potential. Today, the concept of education through art breaks with the ideal of beauty, as well as with the concept of the ideal man. Today's concept of education through art postulates the possibility of penetration through art into the essence of man's fate, in his experience, feelings, condition (Wojnar, 1970, p.131). Looking at education through art in this way, it is not difficult to see the educational aspects in contemporary art. Education does not ignore art which gives pleasure and entertainment, art which "heals" (art therapy), art which makes us aware of new problems of the present, art that speaks more or less complicated languages, art that builds relationships or gives an opportunity to be alone with ourselves. The theory of aesthetic education has placed great hopes in art: art enriches the integrated image of a man, arms humanistic values, so neglected in the modern world, teaches tolerance, requires critical reflection on reality, increases the plasticity of mind and sensibility, has influence on personality in moral and intellectual aspects, triggers creative expression and imagination so much needed in today's world. "Life among art confirms the richness of human invention, develops acumen, sensitizes to new things, unknown, unexpectedly close. Life among art becomes an ally of the idea of education of open mind and rich imagination" (Suchodolski \& Wojnar, 1972, p. 251). At the same time, art provides information about people of today and life in the past, about the development of the world, customs, needs and anxieties 
in history, it creates possibility of reviving traditions. When we look at the theories of the end of art, we should also ask about the theory of aesthetic education, the education "for" and "through" art - art, which according to some, is just ending its life.

We also realize that contemporary art requires intellectual effort from the receiver. To understand new art we need to engage intellectually - we cannot contemplate it aesthetically. Danto (2014), who presents the end of art in a way that is not catastrophic, emphasizes that today it is not the beauty and representational power, but the theory inscribed in beauty which establishes it as an art element. It is not a comfortable situation for the recipient, who should be equipped with a huge theoretical luggage. Since the new paradigm promotes pluralism, eliminates depth and exposes the discursive aspects of art, a recipient may have some difficulty with accepting that today in art, everything is possible. "For art to exist there does not even have to be an object to look at, and if there are objects in a gallery, they can look like anything at all" (Danto, 2014, p.16). In my opinion Danto's philosophy of art is particularly interesting from the perspective of education "for" and "through" contemporary art and requires a careful analysis, for which at this point, unfortunately, there is no space. It should be noted, however, that at a time when visuality has ceased to be equally important for the essence of art, as beauty did (Danto, 2014, p.16), education for art begins to have prime importance in opening people to contemporary art, its specific "form" and "language". Danto claims, that contemporary art has one feature that distinguishes it from art in the past: its primary ambitions are not aesthetic. "Its primary mode of relationship is not to viewers as viewers, but to other aspects of the persons to whom the art is addressed, and hence the primary domain of all such art is not the museum itself, and certainly not public spaces constituted as museums by virtue of having been occupied by works of art which are primarily aesthetic, and which do address persons primarily as viewers" (Danto, 2014, p.183). Danto uses the term disturbatory art in the context of art, which disrupts the established order. Through the experience of this art the mentality of the recipient can be changed. This sort of art uses artistic significance in order to arrange the social or moral changes (Danto, 1997, p. 297).

Therefore, in the face of art after the end of art, the time has come to consider aesthetic education after the end of art. It is essential that from the visual perspective anything could be a work of art. This does not mean that art is over. It means that if we are going to find out what art is, we have to turn from sensory experiences to thought - to philosophy (Danto, 2014). Catastrophic feelings towards art steam not from too excessive expectations of it, but from the fact that traditional aesthetic categories do not apply to contemporary art. In my opinion this is the most important issue in education through con- 
temporary art. Today's artists, liberated from the burden of history, are free to make art whatever they wish, for any purposes they wish or for no purpose at all. That is the important feature of contemporary art. And that is the issue which should be taught by an aesthetic educator.

\section{CONCLUSION}

Finally, I would like to emphasize pedagogical confidence in art. As an aesthetic educator I am sure about the future of art. Art is changing but it is still alive. Today's works of art are different from the art of the past but they are connected with the contemporary world and they say something about our life here and now. The world of contemporary art is a very small portion of the vast postmodern world, in which individuals are members of many communities and networks. People participate in many discourses, present conflicting ideas and images of the word, receive and impart messages from everybody and to everyone. "The concept of pluralism, acceptance of multiple points of views, respect for the notion of cultural diversity, attention to little narratives over and above meta-narratives are defining the parameters for a new way of conceiving of art (...)" (Sahasrabudhe, 2006, p.90). Its language is changing and it requires from us to get rid of our habits in ways of interpretation of art. This might be difficult but it is the most important task for people who educate through art: to help make students open towards new art, to encourage them to find their own individual interpretation. Historically there have been a few theories about the end of art. Today we also hear voices about the crisis of art. But the inspiration for us, aesthetic educators, may be the words of Herbert Read, who wrote: "States rise, flourish for a while, and fall. Religions, if they do not altogether disappear, are transformed beyond the recognition of their founders and apostles. But art remains - permanent and indestructible, accumulative, but ever free - ever, on its immediate fringes, active and expansive" (Read, 1958, s.328).

\section{REFERENCES}

Adorno, T.W. (1974). Filozofia nowej muzyki. Warszawa: PIW. [English edition: (2004) Philosophy of Modern Music. London, New York: Continuum]

Adorno, T.W. (1990). Sztuka i sztuki [Art and the Arts] In Sztuka i sztuki. Wybor esejow [Art and the Arts. Selected Essays].Warszawa: PIW.

Adorno, T.W. (2002). Aesthetic Theory. London, New York: Continuum.

Bauman, Z. (2000). Globalization: the human consequences. New York: Columbia University Press.

Danto, A.C. (2014). After the End of Art. Contemporary Art and the Pale of History. Princeton and Oxford: Princeton University Press. 
Danto, A.C.(1997). Encounters and Reflections: Art in the Historical Present. Berkeley, Los Angeles, London: University of California Press.

Fromm, E. (2008). To Have or To Be. London, New York: Continuum.

Hegel, G.W.F. (1975). Hegel's Aesthetics: Lectures on Fine Art. Oxford: Clarendon Press.

Kuspit, D. (2006). Koniec sztuki. Gdansk: Muzeum Narodowe w Gdansku. [English edition: (2004). The End of Art. New York: Cambridge University Press]

Ortega y Gasset (1956). The dehumanization of art. In The dehumanization of art and other writings on art and culture. New York: Doubleday \& Company, Garden City.

Read, H. (1958). Education through Art. London: Faber and Faber.

Read, H.(1973). O pochodzeniu formy w sztuce. Warszawa: PIW. [English edition: (1965) The Origins of Form in Art. Thames \& Hudson, London].

Sahasrabudhe, P. (2006). Design for learning through the arts. International Journal of Education Through Art, 2, 77-92.

Suchodolski, B. \& Wojnar, I. (1972). Nasza wspolczesnosc a wychowanie [Our Contemporaneity and Education].Warszawa: Nasza Ksiegarnia.

Tolstoj, L. (1980). Co to jest sztuka? [What is Art?]. Krakow: Wydawnictwo Literackie.

Witkiewicz, S.I. (1992).Upadek sztuki [The Collapse of Art]. In Nowe formy w malarstwie i wynikajace stad nieporozumienia. [New Forms in Art and the Resulting Misunderstanding]. Skierniewice: Wydawnictwo Fis.

Wojnar, I. (1970). Estetyka i wychowanie [Aesthetics and Education].Warszawa: PWN.

Corresponding author at: Barbara Kwiatkowska-Tybulewicz, Faculty of Education, University of Warsaw, 16/20 Mokotowska St., 00-561 Warsaw, Poland E-mail: b.kwiatkowska@uw.edu.pl 